\title{
Pengaruh Bentuk Latihan Squat Jump Terhadap Kekuatan Shooting Sepak Bola Atlet Pro:Direct Academy
}

\author{
John Arwandi ${ }^{1}$, M. Ridwan ${ }^{2}$, Roma $\operatorname{Irawan}^{3}$, Vega Soniawan ${ }^{4}$ \\ ${ }^{1234}$ Fakultas Ilmu Keolahragaan, Universitas Negeri Padang, Indonesia \\ E-mail: johnarwandi@fik.unp.ac.id,m.ridwan@ fik.unp.ac.id, romairawan@ fik.unp.ac.id, \\ vegasoniawan@fik.unp.ac.id
}

Menerima: 10 Oktober 2020; Revisi: 11 November 2020; Diterima: 15 November 2020

https://doi.org/10.24036/MensSana.050220.11

\begin{abstract}
The problem being addressed in this research was the shooting power of athletes which was still below the expected standard, shown by the total number of shooting attempts performed by the athletes both during the match and training sessions i.e. very few athletes could produce goals. This study aims to find out the effect of squat jump exercise on the shooting ability in soccer games athletes played in Pro: Direct Academy. The method used in this study was experimental research with a quantitative data collection technique. 85 athletes hired and trained by the Pro: Direct Academy. Meanwhile, the sampling technique employed was purposive sampling with the athletes who continuously practiced for a year; they were 20 athletes of U17-U18. The data were analyzed by using a $t$-test that the result indicated that $t$-count to the power test result was 3,548. The value of the $t$-count was higher than that of the t-table with 19 free degrees and the level of the significance of $1 \%$ was 2,539. Thus, it can be concluded that the treatment of squat jump exercise has a significant impact on the athletes' shooting power in soccer games.
\end{abstract}

Keywords: Squat Jump Exercise, Shooting Power, Soccer

\begin{abstract}
Abstrak
Masalah dalam penelitian ini adalah kekuatan shooting atlet masih jauh dari yang diharapkan, karena terbukti dari banyaknya shooting yang dilakukan oleh atlet baik dalam pertandingan maupun latihan sangat sedikit yang bisa menghasilkan gol. Penelitian ini bertujuan untuk mengetahui pengaruh bentuk latihan squat jump terhadap kemampuan shooting di dalam permainan sepak bola atlet Pro:Direct Academy. Metode yang digunakan dalam penelitian ini adalah penelitian eksperimen dengan pengambilan data kuantitatif. Populasi dalam penelitian ini adalah seluruh atlet Pro:Direct Academy sebanyak 85 orang. Teknik sampling yang digunakan pada penelitian ini yaitu purposive sampling, dengan kriteria atlet yang sudah berlatihselama setahun. Maka sampel dalam penelitian ini adalah atlet U17-U18 sebanyak 20 orang. Analisa data menggunakan uji-t. Hasil penelitian yang diperoleh menunjukan bahwa t-hitung untuk hasil tes kekuatan sebesar 3,548, di mana nilai tersebut lebih besar dari nilai tabel dengan derajat bebas 19 dan taraf signifikansi sebesar $1 \%$ yaitu 2,539. Sehingga dapat disimpulkan bahwa perlakuan berupa latihan squat jump memberikan pengaruh yang signifikan terhadap kekuatan shooting di dalam permainan sepak bola.
\end{abstract}

\section{Kata Kunci: Latihan Squat Jump, Kekuatan Shooting, Sepak Bola} PENDAHULUAN

Puluhan tahun terakhir, sepakbola salah satu dari cabang olahraga yang berkembang pesat di Indonesia, beberapa puluhan tahun belakangan ini berkembang dengan pesat. Hal tersebut terlihat dari banyaknya orang yang menggemari sepak bola baik sebagai penonton maupun sebagai pelaku dari permainan itu sendiri. Perkembangan ini tidak hanya terjadi di perkotaan saja melainkan sudah masuk ke ranah pedesaan.

Di samping itu sepak bola tidak hanya digeluti oleh para lelaki tetapi juga para wanita dimana banyak wanita yang sudah terlibat dalam 
permainan sepak bola. Sepak bola merupakan permainan yang membutuhkan banyak energi, kepintaran di dalam lapangan memacu semangat, sekaligus memberikan kegembiraan melalui kebersamaan dalam sebuah tim (Syukur \& Soniawan, 2015).

Fenomena lain dari perkembangan ini juga ditandai dengan bertambahnya perkumpulan atau klub sepak bola, academy sepak bola, pusdiklat, ekstrakurikuler dan lain sebagainya. Sepak bola adalah suatu permainan yang dilakukan dengan cara menendang bola yang dilakukan oleh para pemain dengan sasaran gawang dan bertujuan memasukkan bola ke gawang lawan (Ridlo, Faiz \& Saifulloh, 2018).

PSSI merupakan asosiasi sepak bola di Indonesia yang sudah menciptakan wadah kompetisi bertingkat untuk para pelaku Sepak bola dalam rangka melakukan proses peningkatan kemampuan para atlet. Pembinaan prestasi dalam olahraga sepak bola secara berjenjang dan berkelanjutan mempunyai implikasi terhadap pentingnya evaluasi yang harus dilaksanakan secara berkala sejak tahap penyaringan atlet sampai dengan tahap akhir pelaksanaan program latihan dan prestasi yang dicapai. Olahraga prestasi harus dilakukan pembinaan dari semua pihak yang dimulai secara berjenjang dan berkelanjutan, yang berbasis pada pengembangan olahraga untuk semua orang (Setiawan, Y, Amra, F, \& Lesmana, 2018).

Dalam meningkatkan prestasi para atlet dalam bermain sepak bola banyak faktor yang perlu mendapatkan perhatian. Faktor yang mempengaruhi untuk mendapatkan prestasi, seperti kondisi fisik, teknik, taktik, dan mental (Soniawan, V,. \& Irawan, 2018). Keempat faktor ini akan terkait antara satu sama lain dalam mencapai prestasi yang diinginkan. Sehingga tidak satu pun dari keempat faktor ini yang bisa diabaikan apalagi dilupakan terlebih lagi bagi para pembina sepak bola untuk meningkatkan kualitas suatu tim sepak bola.

Pencapaian prestasi dalam olahraga sepak bola memerlukan kondisi fisik atlet secara keseluruhan, dan merupakan salah satu faktor terpenting yang harus dipertimbangkan sebagai proses latihan untuk mencapai prestasi yang tertinggi. Menurut (Syafruddin, 2014) komponen kondisi fisik terdiri dari kekuatan (strength), dayatahan (endurance), kecepatan (speed), kelentukan/ kelenturan (flexibility), daya ledak (explosive power), kelincahan (agility), koordinasi (coordination), keseimbangan

(balance), ketepatan (accuracy), reaksi (reaction). Kondisi fisik adalah satu kesatuan utuh dari komponen-komponen yang tidak dapat dipisahkan begitu saja, baik peningkatan maupun pemeliharaannya (Setiawan, 2013). Sehingga kondisi fisik atlet sepak bola harus dikembangkan dan ditingkatkan sesuai dengan ciri karakteristik.

Kondisi fisik merupakan suatu persyaratan yang harus dimiliki oleh seorang atlet sepak bola didalam meningkatkan dan mengembangkan prestasi olahraga yang optimal, sehingga kondisi fisiknya harus dikembangkan dan ditingkatkan sesuai dengan ciri, karakteristik, dan kebutuhan masing-masing cabang olahraga (Ridwan, 2020). Artinya bahwa didalam usaha peningkatan kondisi fisik, maka seluruh komponen harus dikembangkan.

Melatih atlet sepak bola terutama dalam meningkatkan kapasitas aerobik maskimal yang pada nantinya dapat menopang terciptanya koordinasi gerak lain yang diperlukan pada spesifikasi dalam cabang olahraga bola seperti; kecepatan, kelentukan, keakuratan, dayatahan, kekuatan, kelincahan, power (Kamaruddin, 2011).

Shooting merupakan salah satu dari kemampuan teknik yang perlu mendapatkan perhatian. Sebab melalui shooting sebuah gol sering terjadi dalam sebuah permainan Sepak bola. Dengan banyaknya gol yang bisa dihasilkan ke gawang lawan dan menghindari gol yang terjadi di gawangsendiri itu akan membawa sebuah tim dapat mencapai sebuah kemenangan dalam pertandingan. Shooting adalah upaya keras atlet menyerang memasukkan bola ke gawang lawan untuk mencetak gol sehingga meraih angka untuk kemenangan tim (Batty, 2007).

Shooting dapat menggunakan punggung kaki. Aspek terpenting dalam membentuk adalah kaki tumpuan, penempatan sudut kaki tumpuan sangat menentukan arah, perkenaan kaki dengan bola dan kekuatan tendangan (Indra, P,. \& Marheni, 2020). Salah satu kondisi fisik yang diduga berpengaruh terhadap kemampuan shooting adalah kekuatan (strength) terutama kekuatan otot tungkai.

Kekuatan adalah komponen yang sangat penting guna meningkatkan kondisi fisik secara keseluruhan, salah satu faktor yang berperan dalam pencapaian tendangan adalah faktor kondisi fisik kekuatan otot tungkai, dengan kata 
lain untuk mencapai tendangan yang kuat harus ada unsur kondisi fisik terutama kekuatan otot tungkai yang digunakan untuk mengangkat paha dan menendang bola. Kekuatan otot tungkai ini digunakan saat lari menggiring bola, dan menendang bola. Dengan memiliki otot tungkai yang kuat maka tendangan akan semakin kuat.

Meningkatkan kekuatan otot tungkai yang diharapkan, banyak bentuk-bentuk latihan yang bisa dipergunakan. Peningkatan prestasi atlet Sepak bola harus melaksanakan latihan sangat menentukan dalam pencapaian prestasi. Bentuk latihan yang dipilih juga akan sangat menentukan dalam mencapai target latihan yang diinginkan (Ardianda \& Arwandi, 2018).

Adapun bentuk-bentuk latihan tersebut seperti leg press, leg extension, leg curle, jump to box,double leg speed hop, single leg speed hop, squat jump, knee tuck jump, dan lain sebagainya. Dari semua bentuk latihan ini bisa digunakan untuk meningkatkan kekuatan otot tungkai. Masing-masing bentuk latihan tidak akan terlepas dari kelebihan dan kekurangan pada pelaksanaannya. Squat jump yang merupakan salah satu bentuk latihan yang didugabisa digunakan untuk meningkatkan kekuatan otot tungkai yang juga nantinya akan bermuara terhadap peningkatan kemampuan atlet dalam melakukan shooting.

Squat Jump adalah satu gerakan olahraga yang dilakukan dengan sikap awal subjek berdiri dengan tangan berada di belakang kepala, jarak kedua kaki 4-6 inci dengan tumit dari kaki berada di atas dan segaris dengan jari jari kaki kanan, berat badan bertumpu pada tumit kanan, kemudian langsung melompat kembali ke atas, kedua lutut lurus waktu berada diudara dan jatuhkan berat badan yang bertumpu ke kaki kiri (Widiastuti, 2011).

Gerakan squat jump yaitu gerakan memantul-mantulkan tubuh ke atas dan kebawah dengan sikap badan tegak lurus saat diudara dan kedua kaki ditekuk saat mendarat dan sikap tangan saling berpegang satu sama lainnya dibelakang kepala dengan keadaan kedua siku menghadap kesamping badan secara lurus (Sukadiyanto, 2011).

Bentuk latihan squat jump ini tidak membutuhkan tempat yang khusus dan gerakannya sangat sederhana, mudah untuk dipelajari, dipahami dan diaplikasikan oleh para atlet. Disaat melompat kedua kaki lurus dan disaat mendarat kedua kaki ditekuk 90 derajat dengan sikap kedua kaki satu didepan dan satu dibelakang kemudian melompat lagi dengan cepat seperti semula dan saat mendaratnya terjadi pergantian antara kaki kiri dan kanan untuk didepan dan dibelakangnya. Gerakan squat jump sama halnya seperti gerakan pada saat melakukan teknik shooting yaitu menekukkan tungkai. Berdasarkan hal tersebut, diberikan latihan squat jump untuk meningkatkan kekuatan shooting atlet Sepak bola. Jadi, penelitian ini pengaruh bentuk latihan squat jump terhadap kekuatan shooting di dalam permainan sepak bola.

Berdasakan hasil observasi dan diskusi dengan pelatih Pro:Direct Academy kelompok U17-U18, ternyata kekuatan shooting para atletnya masih jauh dari yang diharapkan. Hal ini terbukti dari banyaknya shooting yang dilakukan oleh para atlet baik dalam pertandingan maupun latihan sangat sedikit yang bisa menghasilkan gol.

Dari shooting yang dilakukan para atlet bola pada umumnya sudah mengarah kesasaran yang tepat, akan tetapi bola tersebut masih bisa diantisipasi dan dijangkau oleh para penjaga gawang. Karena kekuatan dari hasil shooting tersebut masih kurang. Jika hal tersebut dibiarkan maka prestasi yang di inginkan akan sulit untuk dicapai.

Berdasarkan dengan hal tersebut, peneliti mengangkat permasalahan ini dalam bentuk penelitian yang berjudul "Pengaruh Bentuk Latihan Squat Jump Terhadap Kekuatan Shooting Sepak Bola Atlet Pro:Direct Academy". Mengacu pada judul penelitian tersebut, maka permasalahan penelitian ini adalah apakah pemberian latihan squat jump ada implikasinya dalam meningkatkan kekuatan shooting Sepak bola. Urgensi temuan penelitian ini dapat dijadikan acuan dan rekomendasi bagi para akademisi, pelatih dan stake holder sepak bola bahwa latihan squat jump dapat dijadikan alternatif sebagai salah satu bentuk latihan yang dapat digunakan dalam meningkatkan kekuatan shooting sepak bola.

\section{METODE}

Penelitian ini menggunakan metode penelitian eksperimen, tujuannya adalah untuk mengetahui ada tidaknya pengaruh perlakuan antara sebab dengan akibat yang sifatnya membandingkan antara variabel-variabel yang dikontrol (dependent variables dan independent variables) (Sugiyono, 2015). Pelaksanaannya dengan melakukan pre-test dan post-test setelah 
melakukan tindakan percobaan penelitian. Penelitian ini dilaksanakan pada Bulan Januari sampai dengan Bulan Februari 2020 di Serena Hills Junior Stadium, Kota Tangerang Selatan, Banten.

Populasi dalam penelitian ini adalah seluruh atlet Pro:Direct Academy berjumlah 85 orang dengan rincian kelompok U6-U9 sebanyak 15 orang, U10-U13 sebanyak 20 orang, U14-U16 sebanyak 20 orang dan U17-U18 sebanyak 20 orang. Teknik sampling yang digunakan pada penelitian ini yaitu purposive sampling, dengan kriteria atlet yang sudah berlatih selama setahun, perkembangan kondisi fisik, dan teknik yang sudah otomatisasi. Berdasarkan kriteria atlet dan sesuai kelompok umur yang diobservasi, maka ditetapkan sampel dalam penelitian ini adalah atlet U17-U18 sebanyak 20 orang.

Penelitian ini bertujuan untuk mengetahui pengaruh bentuk latihan squat jump terhadap kekuatan shooting di dalam permainan sepak bola. Pengambilan data pertama dilakukan pretest ketika sampel belum menerima perlakuan berupa latihan squat jump. Selanjutnya memberikan perlakuan bentuk latihan squat jump terhadap sampel selama $16 \mathrm{kali}$ pertemuan dengan pembagian jadwal latihan pada hari senin, rabu, jumat dan minggu. Setelah itu memberikan penilaian akhir atau post-test untuk melihat sekaligus menilai ada atau tidaknya pengaruh latihan squat jump terhadap kekuatan shooting.

Tes yang digunakan dalam penelitian ini adalahtes kecepatan dankekuatan tendangan yang diciptakan oleh Dedi Ahadiat yaitu alat tes kecepatan dan kekuatan tendangan, dengan mengambil nilai kekuatan shooting yang di keluarkan pada alat. Alat sensor yang terdiri dari beberapa komponen yaitu tombol pengatur jarak shooting, pengatur berat bola, dan terdapat layar alat test kecepatan dan kekuatan tendangan. Alat ini kemudian akan dihubungkan pada sensor yang terdapat pada gawang target melalui kabel, di mana sensor diletakkan pada jaring gawang target.

Gawang target yang digunakan merupakan gawang dengan tinggi 2,44 $\mathrm{m}$ dan panjang 7,32 m. Ukuran panjang dan tinggi gawang dihitung dari sisi dalam tiang dan mistar. Adapun jaring gawang memiliki ukuran lubang sebesar $10 \mathrm{~cm}$. Sedangkan untuk sensor, merupakan alat yang berbentuk segiempat yang berfungsi untuk membaca pergerakan jaring yang akibat tendangan bola. Jarak yang digunakan dalam test ini yaitu 2 meter dari tempat bola ditendang sampai gawang target. Instrumen penelitian adalah alat atau fasilitas yang di gunakan oleh peneliti dalam pengumpulan data agar pekerjaannya mudah dan hasilnya lebih baik.

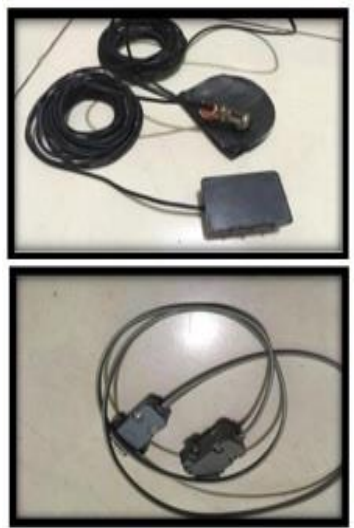

Gambar 1. Alat Tes

Prosedur pelaksanaan alat test kecepatan dan kekuatan shooting pada permainan Sepak bola: (1) Menyiapkan gawang target yang sudah terpasang jaring untuk menempelkan sensor. (2) Menyiapkan lapangan test. (3) Mengoperasikan dan menghubungkan alat test dengan kabel roll yang akan dipakai ke gawang target. (4) Mengatur display test yaitu jarak tendangan, (5) Mengatur target yang dipakai jaring tekan

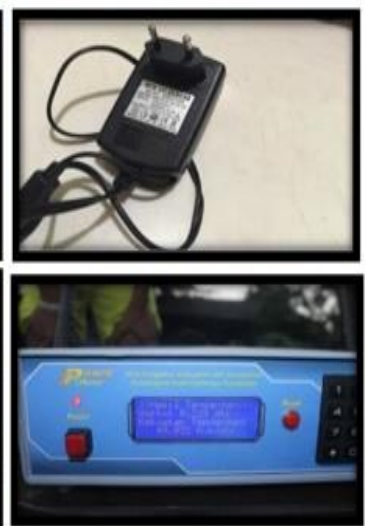

\section{Power Tendangan}

tanda"\#" dan papan tekan tanda, (6) Menyiapkan peralatan berupa alat tulis, bola, meteran, komputer, gawang target, lakban, dan roll kabel. (7) Bola diletakkan pada alas bola pada jarak 2 meter. (8) Testee melakukan tendangan ke arah target dengan keras baik menggunakan punggung kaki, kaki bagian dalam ataupun kaki bagian luar. 
Teknik analisis data yang digunakan pada adalah uji $\mathrm{t}$ berpasangan (Purnomo, W., \& Bramantoro, 2018). Data yang diperoleh adalah data kekuatan tendangan pada sebelum dilakukannya perlakuan dan sesudah dilakukan perlakuan. $t$ tabel pada penelitian ini dapat dilihat dari tabel distribusi t dengan derajat bebas $n-1$. Diperolehnya nilai derajat bebas tersebut maka dapat dicari nilai $t$ tabelnya pada taraf signifikansi yang diinginkan, seperti misalnya pada taraf $1 \%$ atau $5 \%$. Jadi, jika t hitung sama dengan atau lebih besar dari nilai t tabel maka akan ditolak; berarti terdapat perbedaan mean

Tabel 1. Distribusi Frekuensi Tes Awal

Kekuatan Tendangan

\begin{tabular}{ccccc}
\hline No & Kelas Interval & Klasifikasi & Absolut & Relatif \\
\hline & & Kurang & & \\
1 & $7,890-18,047$ & Sekali & 1 & $5 \%$ \\
2 & $18,048-28,255$ & Kurang & 2 & $10 \%$ \\
3 & $28,256-35,463$ & Rendah & 7 & $35 \%$ \\
4 & $35,464-45,680$ & Sedang & 4 & $20 \%$ \\
5 & $45,690-55,870$ & Baik & 2 & $10 \%$ \\
& & Baik & & \\
6 & $55,890-66,088$ & Sekali & 4 & $20 \%$ \\
& Jumlah & & 20 & $100 \%$ \\
\hline
\end{tabular}

Berdasarkan tabel distribusi frekuensi tes awal kekuatan tendangan diatas menjelaskan bahwa diperoleh 1 orang (5\%) dengan kategori kurang sekali, 2 orang (10\%) dengan kategori kurang, 7 orang (35\%) dengan rendah, 4 orang yang signifikan di antara dua variabel yang diuji. Namun, jika t hitung lebih kecil dari nilai t tabel maka akan diterima; berarti tidak terdapat perbedaan antara dua variabel yang diuji.

\section{HASIL DAN PEMBAHASAN Hasil Penelitian}

Hasil pengukuran tes kekuatan tendangan pada saat sebelum dilakukan perlakuan, dilakukan pengujian kekuatan tendangan, sebagai berikut:

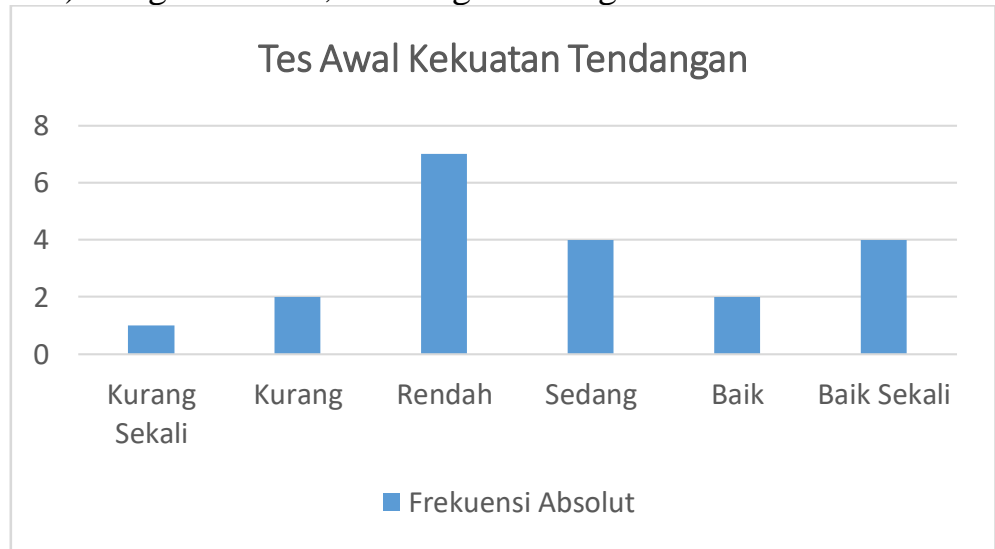

Gambar 2. Histogram Tes Awal Kekuatan Tendangan

Hasil pengukuran tes kekuatan tendangan pada saat setelah dilakukan perlakuan, dilakukan pengujian kekuatan tendangan, sebagai berikut:

Tabel 2. Distribusi Frekuensi Tes Akhir

Kekuatan Tendangan

\begin{tabular}{ccccc}
\multicolumn{5}{c}{ Kekuatan Tendangan } \\
No & Kelas Interval & Klasifikasi & Absolut & Relatif \\
\hline 1 & $7,890-18,047$ & Kurang Sekali & 1 & $5 \%$ \\
2 & $18,048-28,255$ & Kurang & 1 & $5 \%$ \\
3 & $28,256-35,463$ & Rendah & 3 & $15 \%$ \\
4 & $35,464-45,680$ & Sedang & 5 & $25 \%$ \\
5 & $45,690-55,870$ & Baik & 5 & $25 \%$
\end{tabular}




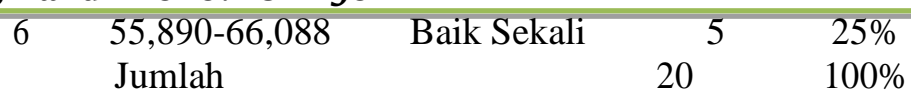

Berdasarkan tabel distribusi frekuensi tes (25\%) dengan kategori sedang, 5 orang (25\%) akhir kekuatan tendangan diatas menjelaskan dengan kategori baik, dan 5 orang (25\%) dengan bahwa diperoleh 1 orang (5\%) dengan kategori kategori baik sekali.. Data tersebut ditampilkan kurang sekali, 1 orang (5\%) dengan kategori melalui diagram batang dapat diperoleh hasil kurang, 3 orang (15\%) dengan rendah, 5 orang sebagai berikut:

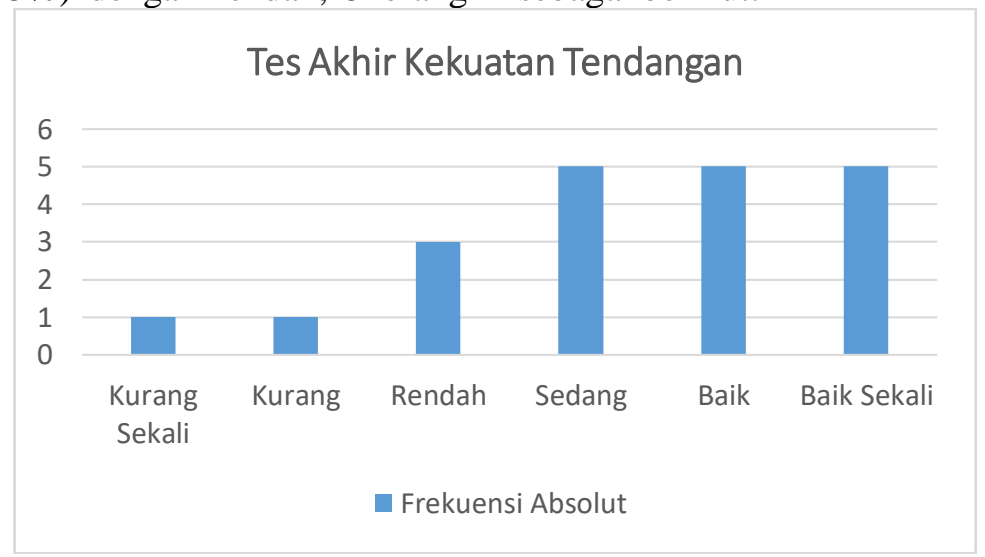

Gambar 3. Histogram Tes Akhir Kekuatan Tendangan

Hipotesis yang digunakan adalah $\mathrm{H}_{0}$ menyatakan bahwa perlakuan tidak memiliki pengaruh terhadap kekuatan tendangan dan $\mathrm{H}_{1}$ menyatakan bahwa perlakuan memiliki pengaruh terhadap kekuatan tendangan. Selanjutnya nilai

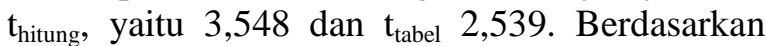
hasil data tersebut, maka $\mathrm{H}_{0}$ dapat ditolak karena $t_{\text {hitung }}>t_{\text {tabel }}(3,548>2,539)$. Jadi, terdapat perbedaan yang signifikan terhadap data variabel pree test dan post test dengan taraf signifikansi sebesar 0,05 , sehingga dapat dikatakan bahwa suatu perlakuan memiliki pengaruh terhadap kekuatan tendangan.

\section{Pembahasan}

Penelitian ini merupakan penelitian eksperimen yang mempunyai tujuan untuk mengetahui ada tidaknya pengaruh perlakuan latihan squat jump terhadap kekuatan shooting di dalam permainan sepak bola yang dilaksanakan pada bulan Februari 2020. Data penelitian yang telah dideskripsikan di atas merupakan data pretest ketika sampel belum menerima perlakuan berupa latihan squat jump. Selanjutnya memberikan perlakuan bentuk latihan squat jump terhadap sampel selama 16 kali pertemuan.

Hasil penelitian pada saat sebelum diberikan perlakuan (pree test) dengan 20 orang atlet memiliki kemampuan shooting dengan ratarata sebanyak 7 orang berada pada kategori rendah. Sedangkan pada saat sesudah diberikan perlakuan (post test) atlet memiliki kemampuan shooting dengan rata-rata sebanyak 5 orang berada pada kategori sedang, baik, dan baik sekali.

Berdasarkan hasil tersebut menunjukkan bahwa latihan squat jump memiliki pengaruh terhadap peningkatan power otot tungkai dan berimplikasi terhadap peningkatan kemampuan shooting. Gerakan squat jump sama halnya seperti gerakan pada saat melakukan teknik shooting (menendang bola) yaitu menekukkan tungkai dan meluruskan tungkai, jika otot ini yang dilatih dengan diberikan beban tubuh kita sendiri yaitu latihan squat jump dilakukan dengan kuat dan cepat maka power shooting yang diharapkan akan bertambah seperti yang dikatakan Johnson, seorang pesepak bola perlu menjadi atlet yang serba bisa, dapat berlari cepat dan menggunakan kekuatan besar otot untuk menendang bola. Squat jump adalah salah satu gerakan olahraga yang dilakukan dengan posisi awal tubuh berdiri dan kaki dibuka lebar (Irawadi, 2014)

Peningkatan kekuatan shooting tersebut di atas disebabkan karena perlakuan latihan squat jump yang bervariasi secara terus menerus dan terprogram. Bentuk dan variasi latihan squat jump yang diberikan secara terus menerus dalam proses latihan selama 16 kali pertemuan ternyata memberikan peningkatan yang cukup berarti, karena saat tes awal (pree-test) dengan tes akhir (post-test), disebabkan variabel bebas yang berpengaruh pada variabel terikat yang diakibatkan oleh program latihan yang diberikan secara intensif dan kontinyu. Selain itu frekuensi 
latihan yang di lakukan 4 kali seminggu merangsang kemampuan motorik tubuh yang pada akhirnya akan meningkatkan kekuatan shooting. Perubahan kemampuan dalam menampilkan suatu keterampilan yang relatif permanen sebagai dampak dari hasil pengalaman belajar atau proses latihan yang berlangsung relatif lama (Magill, 2014).

Shooting merupakan salah satu dari kemampuan teknik yang perlu mendapatkan perhatian. Sebab melalui shooting sebuah gol sering terjadi dalam sebuah permainan sepak bola. Shooting merupakan teknik yang harus dikuasai oleh setiap pemain, teknik ini merupakan cara untuk menciptakan gol, karena seluruh pemain mendapat kesempatan untuk menciptakan gol dalam memenangkan pertandingan (Naldi \& Irawan, 2020).

Kemampuan melakukan shooting dengan kuat dan akurat menggunakan kedua kaki baik kaki kanan maupun kiri adalah faktor yang paling penting, karena keberhasilan seorang atlet sebagai pencetak gol tergantung dari faktor tersebut. Seorang pemain membutuhkan kondisi fisik yang prima untuk menunjang kemampuan pemain dalam menampilkan keterampilan bermain sepak bola dengan maksimal, seperti keterampilan menendang, mengontrol, mendribel, maupun melakukan tendangan ke gawang (Atradinal, \& Sepriani, 2016). Salah satu faktor yang berperan dalam pencapaian tendangan adalah faktor kondisi fisik kekuatan otot tungkai.

Kekuatan merupakan kompenen yang sangat penting dari kondisi fisik secara keseluruhan, karena merupakan daya penggerak setiap aktifitas fisik. Kekuatan adalah kemampuan dari suatu otot untuk bekerja menahan beban secara maksimal (Edwarsyah, 2016). Kekuatan atau strenght adalah komponen kondisi fisik, yang menyangkut masalah kemampuan seseorang atlet pada saat mempergunakan otot-ototnya menerima beban dalam waktu kerja tertentu.

Kekuatan merupakan salah satu unsur kondisi fisik yang sangat penting dalam Sepak bola karena dapat membantu meningkatkan komponen seperti kecepatan, kelincahan dan ketepatan (Chan, 2012). Dengan kata lain, untuk mencapai tendangan harus ada unsur kondisi fisik terutama kekuatan otot tungkai yang digunakan untuk mengangkat paha dan menolak pada saat shooting. Latihan menembak bola (shooting) sangat diperlukan untuk melatih setiap kekuatan pemain dalam menendang bola dan melakukan serangan. baik dari teknik maupun kekuatan otot tungkai pemain tersebut (Maulana, G., \& Irawan, 2020).

Kekuatan otot tungkai seseorang berperan penting dalam meningkatkan frekuensi langkah lari seseorang. Karena frekuensi langkah adalah perkalian antara kekuatan otot tungkai dan kecepatan otot dalam melangkah. Kekuatan otot tungkai ini digunakan saat lari menggiring bola dan shooting dengan otot tungkai yang kuat maka tendangan akan semakin kuat.

Seorang pemain Sepak bola harus memiliki kaki yang kuat, pergelangan kaki yang kuat, lutut yang kuat dan tungkai yang kuat agar dapat memikul badan yang berat. Kekuatan otot tungkai ini digunakan saat lari menggiring bola, dan menendang bola. Dengan memiliki otot tungkai yang kuat maka tendangan akan semakin kuat. Dengan demikian bola yang ditendang ke arah gawang akan semakin sulit untuk diantisipasi oleh seorang penjaga gawang.

Dengan kata lain hasil tendangan ke gawang diduga akan lebih banyak menghasilkan gol yang bisa membawa kemenangan untuk sebuah tim dalam pertandingan yang di ikutinya. Pencapaian kecepatan tendangan bola, kekuatan otot tungkai sangat berpengaruh. Dengan demikian seseorang yang mempunyai kekuatan otot yang baik dapat melakukan dan memikul pekerjaan yang berat dalam waktu yang lama.

Dan orang yang fisiknya segar akan mempunyai otot yang kuat dan mampu bekerja secara efisien. Pada olahraga sepak bola kekuatan otot tersebut diperlukan untuk mengatasi beban yang terdapat pada saat bermain, dan aplikasinya lebih kepada daya dukung untuk kekuatan kondisi fisik. Melakukan gerakan shooting juga melibatkan otot dan persendian seperti halnya pada gerakan squat jump, dalam menendang anggota tubuh yang menjadi pondasi utama adalah anggota gerak bagian bawah yaitu tungkai.

Sedangkan gerakan tangan hanya berayun untuk menjaga keseimbangan dan keserasian gerak. Pada saat gerakan ancang-ancang, persendian bergerak dimulai dari fleksi dari persendian lutut dan panggul serta engkel kaki kanan yang terangkat ke atas. Sedangkan pada saat meluruskan kaki kiri terjadi ekstensi panggul, lutut dan engkel yang memberikan tolakan. Demikian seterusnya hingga pergantian langkah kaki. Pandangan sebelum tendangan harus dikonsentrasikan ke bola sedangkan ketika 
hampir menyentuh bola lihatlah sasaran yang akan dituju dan saat kaki tendang impact dengan bola pergelangan kaki tersebut harus terkunci dengan baik.

Oleh karena itu, berdasarkan hasil penelitian yang diperoleh, maka diharapkan pelatih dan atlet sepak bola selalu memperhatikan kemampuan kondisi fisik sepak bola terutama kekuatan otot tungkai. Karena dengan memiliki kekuatan otot tungkai yang baik akan memberikan pengaruh pada peningkatan kemampuan shooting dalam usaha mencetak gol sebanyak mungkin sesuai dengan ide permainan sepak bola.

\section{KESIMPULAN}

Berdasarkan hasil penelitian dan pembahasan, maka dapat disimpulkan bahwa latihan squat jump memiliki pengaruh terhadap peningkatan power otot tungkai dan berimplikasi terhadap peningkatan kemampuan shooting di dalam permainan sepak bola pada atlet Pro:Direct Academy. Untuk meningkatkan kekuatan shooting dapat menggunakan metode dan bentuk latihan yang lainnya.

Disarankan untuk pelatih dan atlet Pro:Direct Academy serta penelitian selanjutnya dapat menganalisis dan mengembangkan latihan kondisi fisik lain seperti power otot tungkai, keseimbangan dinamis dan kelincahan untuk meningkatkan kemampuan shooting dalam permainan sepak bola.

\section{DAFTAR PUSTAKA}

Ardianda, E., \& Arwandi, J. (2018). Latihan ZigZag Run dan Latihan Shuttle Run Berpengaruh Terhadap Kemampuan Dribbling Sepak bola. Performa Olahraga, $3(01)$, $32-41$. https://doi.org/https://doi.org/10.24036/jpo1 6019

Atradinal, \& Sepriani, R. (2016). Pemulihan Kekuatan Otot Pada Atlet Sepak bola. Jurnal Men, 1(1), 99-105. https://doi.org/https://doi.org/10.24036/jm. v2i2.86

Batty, E. C. (2007). Latihan Metode Baru Sepak bola Serangan. Bandung: Pionir Jaya.

Chan, F. (2012). Strength Training (Latihan Kekuatan). Jurnal Cerdas Sifa Pendidikan,
1(1). Retrieved from https://www.onlinejournal.unja.ac.id/csp/article/view/703

Edwarsyah. (2016). Pengaruh Latihan Front Squat Terhadap Kekuatan Otot Tungkai Atlit Angkat Besi Kota Padang. Jurnal Menssana, 1 No 1(Mei 2016), 75-85. https://doi.org/https://doi.org/10.24036/jm. v1i1.46

Indra, P,. \& Marheni, E. (2020). Pengaruh Metode Latihan dan Motivasi Berlatih terhadap Keterampilan Bermain Sepak Bola Ssb Persika Jaya Sikabau. Jurnal Performa Olahraga, 5(1), 39-47. https://doi.org/https://doi.org/10.24036/jpo1 38019

Irawadi, H. (2014). Kondisi Fisik dan Pengukurannya. Padang: UNP Press.

Kamaruddin, I. (2011). Kondisi Fisik Dan Struktur Tubuh Atlet Sepak bola Usia 18 Tahun Psm Makassar. Jurnal ILARA, 11(2), 81-92.

Magill, R. (2014). Motor Learning \& Control+ Cnct+. McGraw-Hill Education.

Maulana, G., \& Irawan, R. (2020). Pengaruh Metode Bentuk Bermain dan Bentuk Latihan Terhadap Kemampuan Shooting Pemain SSB. Jurnal Patriot, 2(2019), 220232. https://doi.org/https://doi.org/10.24036/patr iot.v2i1.635

Naldi, I. Y., \& Irawan, R. (2020). Kontribusi Kemampuan Motorik Terhadap Kemampuan Teknik Dasar pada Atlet Ssb (Sekolah Sepak bola) Balai Baru Kota Padang. Performa Olahraga, 5(2018), 611. Retrieved from http://performa.ppj.unp.ac.id/index.php/kep el/article/view/133/132

Purnomo, W., \& Bramantoro, T. (2018). Pengantar Metodologi Penelitian Bidang Kesehatan. Surabaya: Airlangga University Press.

Ridlo, Faiz \& Saifulloh, I. (2018). Pengaruh Metode Latihan Small Sided Game 
Terhadap Kemampuan Passing-Stopping Permainan Sepak bola. Jurnal Research Physical Education, IX(2), 116-121. Retrieved from http://jurnal.unismabekasi.ac.id/index.php/ motion/article/view/1591

Ridwan, M. S, Afrizal. Soniawan, V. (2020). Kekuatan Musculus Abdominalis Dan Kelentukan Pinggang Berhubungan Dengan Kemampuan Heading Pemain Sekolah Sepak bola. Jurnal Sporta Saintika, 5(2), 149-159.

https://doi.org/https://doi.org/10.24036/spor ta.v5i2.138

Ridwan, M. (2020). Kondisi Fisik Pemain Sekolah Sepak bola (SSB) Kota Padang. Performa Olahraga, 5(2018), 65-72. https://doi.org/https://doi.org/10.24036/jpo1 42019

Setiawan, Y., Amra, F., \& Lesmana, H. S. (2018). Analisis Tentang Cedera Dalam Olahraga Taekwondo Di Dojang UNP. $P$, 1(3), 401-414. https://doi.org/https://doi.org/10.24036/jpo3 9019

Setiawan, D. (2013). Kondisi Fisik Pemain Sepak bola Klub Asyabaab Di Kabupaten Sidoarjo. Jurnal Kesehatan Olahraga, 2(3), 1-5. Retrieved from https://jurnalmahasiswa.unesa.ac.id/index.p hp/jurnal-kesehatanolahraga/article/view/1903

Soniawan, V,. \& Irawan, R. (2018). Metode Bermain Berpengaruh Terhadap Kemampuan Long Passing Sepak bola. Performa Olahraga, 3(01), 42-49. https://doi.org/10.31227/osf.io/6vgxz

Sugiyono, P. D. (2015). Metode Penelitian Kombinasi (Mixed Methods). Bandung: CV. Alfabeta.

Sukadiyanto, \& M. D. (2011). Pengantar Teori dan Metodologi Melatih Fisik. Bandung: CV. Lubuk Agung.

Syafruddin. (2014). Ilmu kepelatihan Olahraga. Padang: UNP Press.
Syukur, A., \& Soniawan, V. (2015). The Effects of Training Methods and Achievement Motivation Toward of Football Passing Skills. Jipes - Journal of Indonesian Physical Education and Sport, 1(2), 73. https://doi.org/10.21009/jies.012.07

Widiastuti. (2011). Tes dan Pengukuran Olahraga. Jakarta: PT. Bumi Timur Jaya. 